\title{
Vasúti közlekedés
}

\section{A vasúti pálya kialakításával, viselkedésével kapcsolatos tudományos kutatás-fejlesztési munkáink eredményei}

Az egyetemi oktatás egyik fontos kritériuma, hogy a lehetö legszorosabb kapcsolatban álljon a müvelt terület mindennapi gyakorlatával, hiszen a hallgatókat a rutinszerü feladatok megoldása mellett az ismeretek komplex, alkotó jellegü használatára is fel kell készíteni. Az oktatók kövessék a müszaki fejlődést és segítsék azon szakmai problémák megoldását, amelyek a magas szintű tudást, az egyetem adta infrastrukturális lehetőségek kihasználását igénylik. Egy egyetem sikerességének fokmérője az oktatás színvonala mellett az, hogy a kutatás - fejlesztés területén milyen eredményeket ér el, amelyek haszna jelentkezik az ipar (a megrendelö) számára, de ugyanilyen fontos az egyetem részére is. Hiszen a létrehozott új tudásanyag azonnal beépülhet az oktatásba, segítheti újabb tudományos témák mưvelését.

DOI 10.24228/KTSZ.2018.1.1

\section{Dr. Horvát Ferenc}

ny. fôiskolai tanár

e-mail: horvat.sze@gmail.com

\section{A KUTATÁS - FEJLESZTÉSI MUN- KÁRÓL}

A kutatás-fejlesztési $(\mathrm{K}+\mathrm{F})$ tevékenység magában foglalja az alapkutatást, az alkalmazott kutatást és a kísérleti fejlesztést. Az alkalmazott kutatás célja új ismeretek és szakértelem megszerzése új termékek, eljárások vagy szolgáltatások kifejlesztéséhez. Cél lehet létező termékek, eljárások vagy szolgáltatások jelentős mértékü fejlesztésének elősegitése is. A kutatás-fejlesztési tevékenység minősítése a Szellemi Tulajdon Nemzeti Hivatalának (SZTNH) hatásköre. A Hivatal arról nyilatkozik, hogy a megvalósítandó projekt kutatásfejlesztési tevékenységnek minősíthetö-e.

A tudományos kutatási tevékenység összetett feladat, amelynek már megtervezése is nagy körültekintést igényel. Első lépés a cél megfogal- mazása, az elérni kívánt tudományos ismeretek részletezése. Ez azonban csak a kiindulás, hiszen a munka előrehaladása során nehézségek, újabb megoldandó (rész)feladatok is felmerülhetnek, amelyek az eredeti kutatási programot jelentősen megváltoztathatják. A kutatónak tisztában kell lennie azzal, hogy elképzelései megvalósítását, a kívánt eredmény elérését tudományos bizonytalanságok nehezíthetik. Ezekre már a munka tervezése során fel kell készülni. Meg kell fogalmazni azokat az alternatívákat, amelyek a bizonytalanságok ellenére, azok feloldása után, lehetővé teszik a cél elérését.

Rendkívül sokat jelent a munka sikeres megvalósítása céljából a megrendelést adó cég szakmai és gyakorlati támogatása. A vasúti pályával kapcsolatos kutatási munkák sok esetben laboratóriumi vizsgálatokat, helyszí- 


\section{Vasúti közlekedés}

ni teszteket követelnek. A mintadarabok biztosításában, a teszthelyszínek kialakításában a megrendelő segítsége nélkülözhetetlen. A konzultációk és a beszámolók pedig azok a fórumok, ahol az eredmények folyamatos értékelése, az esetleges módosított igények megfogalmazása történik.

Fontos az is, hogyan hasznosul a $\mathrm{K}+\mathrm{F}$ munka eredménye a megrendelönél, amit a felhasználó anyagi lehetőségei jelentősen befolyásolnak. Egy meg nem valósult kutatási munkának is van azonban mindig olyan eredménye, amely az oktatásba beépülve, közvetve hasznosul, illetve publikációk keretében ad a szakma számára tájékoztatást az új ismeretekről.

Kutatási munkáim általában az alábbi célok elérésére irányultak:

- valamely jelenség nem (kellően) ismert okának, az ok és okozat összefüggése törvényszerüségeinek megfogalmazása,

- új módszer, megoldás, eszköz megfelelőségének igazolása, az esetleg szükséges módosítások megfogalmazása.

A következő fejezetekben a MÁV Zrt. számára az elmúlt években végzett két $\mathrm{K}+\mathrm{F}$ munka eredményeit foglaltam össze.

\section{VILLAMOS VONTATÁSSAL ÜZE- MELTETETT VASÚTI PÁLYÁKON A SEBESSÉGKORLÁTOZÁSOK OKOZTA TÖBBLETKÖLTSÉGEK CSÖKKENTÉ- SI LEHETÖSÉGEINEK VIZSGÁLATA}

A többéves K+F munka 2012-ben záródott [1]. Bár mára a vizsgált 1 . sz. fővonal lassújel állományában és a vontatáshoz használt áram egységárában változások történtek, de az eredmények - jelentőségük miatt - ma is nagyon figyelemre méltóak.

A vasúti pályahibák következtében bevezetett sebességkorlátozások növelik a menetidőt, gyorsítják a fékbetétek kopását, de mindenekelőtt a lassújelek utáni gyorsítások jelentős többletenergia-felhasználást jelentenek. A hazai pályahálózaton található hibahelyek felszámolásával, a rossz vágány- geometriájú szakaszok javításával jelentős nagyságrendü vontatási energia takarítható meg.

A sebességkorlátozások után szükséges gyorsítási vontatási energiák meghatározására pontos módszer a vontatójárművön történő mérés. A Magyarországon használt mozdonyok és motorvonatok három típusa esetén van mód a vezetőfülkében a számláló nullázásától az adott pillanatig elhasznált vontatási energiák kijelzésére és leolvasására: Siemens Taurus (MÁV 1047, ÖBB 1116), Stadler Flirt (MÁV 5341) és Bombardier Talent (MÁV 5342). A Siemens Taurus mozdonyok által vontatott gyors- és tehervonatokon, valamint a Flirt és Talent motorvonatokon voltak mérések, továbbá kiegészítő méréssorozat készült több ÖBB Railjet szerelvénnyel. A mérések Hegyeshalom és Győr állomások között történtek. Itt a vonalvezetés $\mathrm{v}=160 \mathrm{~km} / \mathrm{h}$ sebességü futást is lehetővé tett. Az egyenes és közel vízszintes vonalvezetés nem torzította az energiafogyasztási eredményeket, a vágányok geometria állapota is jó volt.

A mérések során az volt a tapasztalat, hogy a gyorsítások energiaigénye nagyban függ a vezetési stílustól is, azaz egy dinamikusabban vezető „vezér” ugyanazon a vonalon, ugyanazon sebességkorlátozás-állomány esetén több energiát használ el azonos tömegü szerelvénnyel, mint egy nyugodtabb stílussal vezető. Ezt az eltérést jól mutatja az 1. ábra, amely ugyanazon a napon, Hegyeshalom és Győr állomások között, a jobb vágányon közlekedő két Railjet szerelvényen végrehajtott mérés eredményeit mutatja. A menetidő tartásának érdekében gyakorolt intenzív vezetési mód energiafelhasználása mintegy $20 \%$ többletet eredményezett, míg a takarékos stílus miatt kisebb késés következett be. (Megjegyzés: A Railjet egységszerelvények mozdonya vezetőfülkéjében üzemelö, folyamatosan mérő, a teljes vontatási energiafelhasználás meghatározását lehetővé tevő berendezés a szerelvény fütés-hűtési és segédüzemi energia felvételét nem különíti el a vonattovábbítási energiától.) A bal vágányon történt három mérés diagramjait a 2. ábra mutatja. 


\section{Vasúti közlekedés}

1. ábra: A jobb vágányon 2011. novemberében történt két mérés sebesség, illetve felhasznált energia diagramjai

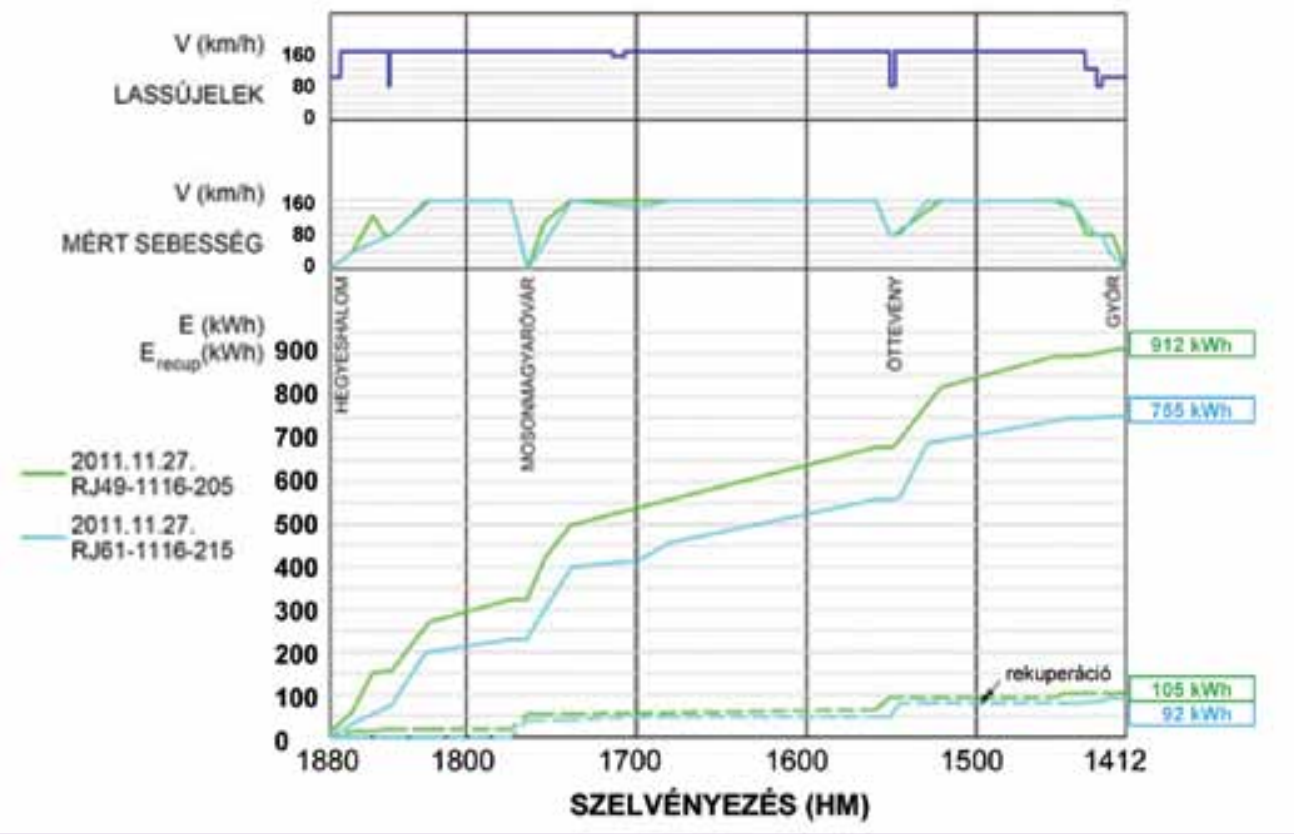

2. ábra: A bal vágányon 2011. novemberében történt három mérés sebesség, illetve felhasznált energia grafikonjai

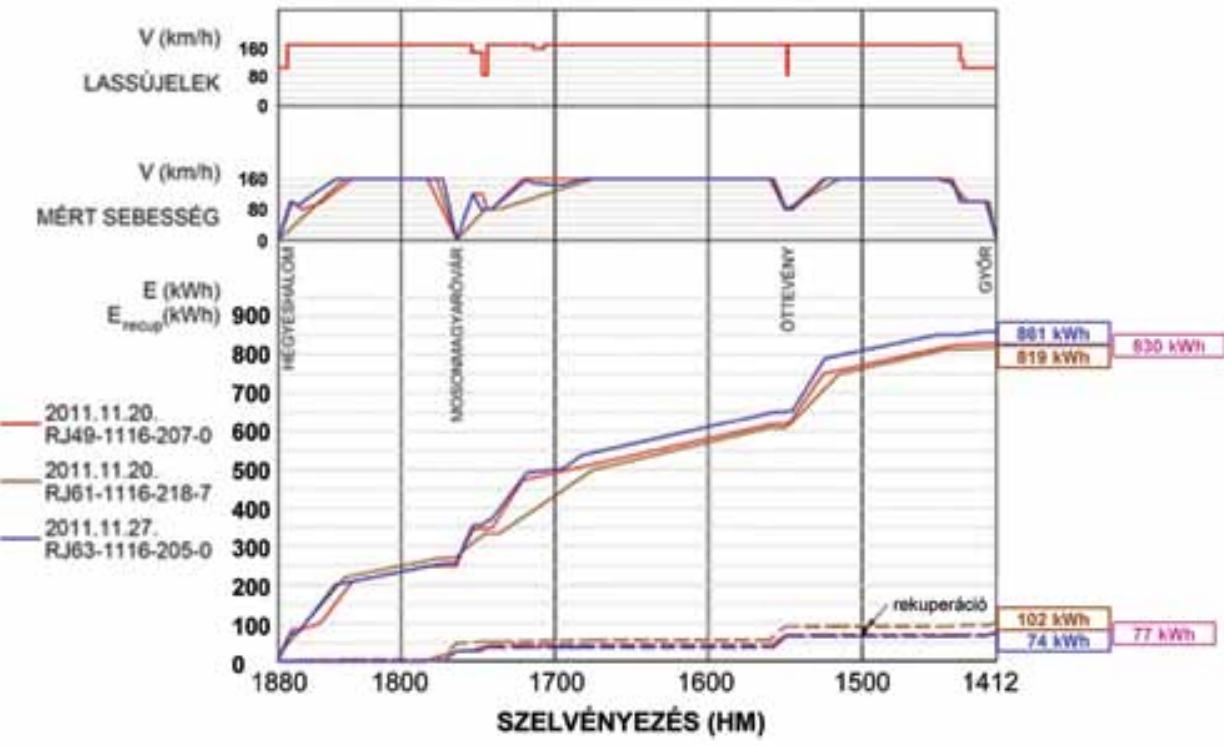




\section{Vasúti közlekedés}

\section{1. táblázat: A 2011. novemberi mérések összesített adatai}

\begin{tabular}{|c|c|c|c|c|c|}
\hline Jellemző & $\begin{array}{c}\text { 2011. 11. } 20 . \\
\text { RJ49 } \\
\text { bal } \\
\text { vágányon }\end{array}$ & $\begin{array}{c}\text { 2011. 11. } 20 . \\
\text { RJ61 } \\
\text { bal } \\
\text { vágányon }\end{array}$ & $\begin{array}{l}\text { 2011. 11. } 27 . \\
\text { RJ49 } \\
\text { jobb } \\
\text { vágányon }\end{array}$ & $\begin{array}{c}\text { 2011. 11. } 27 . \\
\text { RJ61 } \\
\text { jobb } \\
\text { vágányon }\end{array}$ & $\begin{array}{c}\text { 2011. 11. } 27 . \\
\text { RJ63 } \\
\text { bal } \\
\text { vágányon }\end{array}$ \\
\hline Energiafelhasználás ( kWh) & 830 & 819 & 912 & 755 & 861 \\
\hline Mozdonyvezetői stílus & normál & normál & intenzív & takarékos & normál \\
\hline Menetidő & $\begin{array}{l}23 \text { perc } 12 \\
\mathrm{mp}\end{array}$ & $\begin{array}{l}23 \text { perc } 22 \\
\mathrm{mp}\end{array}$ & $\begin{array}{l}24 \text { perc } 05 \\
\mathrm{mp}\end{array}$ & $\begin{array}{l}26 \text { perc } 17 \\
\mathrm{mp}\end{array}$ & 22 perc $33 \mathrm{mp}$ \\
\hline Rekuperált energia (kWh) & 77 & 102 & 105 & 92 & 74 \\
\hline \multicolumn{6}{|l|}{ Energiafelhasználás (kWh) } \\
\hline 1764-1699 szelvények között & - & - & - & 179 & 243 \\
\hline \multicolumn{6}{|l|}{ Energiafelhasználás (kWh) } \\
\hline 1764-1559 szelvények között & 362 & 336 & 354 & 322 & 393 \\
\hline \multicolumn{6}{|l|}{ Fütés, segédüzemi fogyasztás } \\
\hline \multicolumn{6}{|l|}{ (kWh/perc) } \\
\hline Hhalom és Móvár állomásokra & 5 & 3 & 4 & 3 & 2 \\
\hline $\begin{array}{l}\text { Fajlagos energiafelhasználás reku-perációval } \\
(\mathrm{kWh} / 100 \text { vötkm) }\end{array}$ & $\begin{array}{l}3,554 \\
3,224\end{array}$ & $\begin{array}{l}3,507 \\
3,070\end{array}$ & $\begin{array}{l}3,905 \\
3,456\end{array}$ & $\begin{array}{l}3,233 \\
2,839\end{array}$ & $\begin{array}{l}3,687 \\
3.370\end{array}$ \\
\hline
\end{tabular}

$\mathrm{Az}$ energiafelhasználási mérések eredményeinek összesítése az 1. táblázatban található.

A v $v_{0}$-ról v sebességre történő gyorsítás esetén a mozgási energia nagysága a következő módon számítható:

$$
E_{s z}=0,5 \cdot m \cdot\left(v^{2}-v_{0}^{2}\right)[\mathrm{J}],
$$

ahol:

„m” a teljes szerelvény (mozdony+kocsik) tömege kg-ban,

„V” és „V $\mathrm{V}_{0}$ a sebességlépcső alsó és felső értéke $\mathrm{m} / \mathrm{s}$ dimenzióban.

A gyorsításhoz felhasznált energia számításához alkalmazható formula a következő:

$$
E=\alpha \cdot E_{s z}
$$

ahol:

„E” a vontatójármü által a gyorsításkor mért (felhasznált) villamos energia [kWh], "a" a vontató jármütől és a szerelvény jellegétől (személyszállító illetve tehervonat) függő szorzótényező, „E $\mathrm{E}_{\mathrm{sz}}$ ” az (1) képlet szerint számított érték.

A Taurus villamos mozdonyok vontatta szerelvényekre vonatkozó számított és mért gyor- sítási energia diagramok láthatók a 3. ábrán. A regressziós egyenletek együtthatói a (2) képlet a tényezőit szolgáltatják.

Hasonló mérések és adatfeldolgozások történtek Stadler Flirt motorvonatok esetében is.

Amennyiben egy vasútvonalra a teljes villamos vontatási energiafogyasztást kívánjuk meghatározni, akkor egyéb vontatójármüvek esetében is korrekt adatokra van szükségünk. Ehhez futási kísérleteket kellett elvégezni, amelyeket az akkor még létezett MÁV VMMSZK (Vasúti Mérnöki és Mérésügyi Szolgáltató Központ) hajtott végre. A mérőszerelvényben elöl a vizsgált villamos vonómozdony, mögötte a DMK 002 pályaszámú vontatási mérőkocsi haladt, majd a harmadik tag az 1047 sor. villamos mozdony volt. A vontatást a V43 sor. 1338 illetve a V63 sor. 151 villamos mozdony végezte. A DMK 002 pályaszámú vontatási mérökocsi önsúlya $41 \mathrm{t}$, féksúlya 61 t. A fékezési szimulációt minden esetben ugyanaz az 1047 sor. Taurus villamos mozdony látta el a szerelvény harmadik tagjaként. A mozdony $240 \mathrm{kN}$ fékerő kifejtésére volt képes. A mérések Öttevény és Hegyeshalom állomások között történtek.

A számított és mért gyorsítási energia értékeke alapján végül a (2) képlet a tényezőjének értékeit az 2. táblázatban foglaltam össze. 


\section{Vasúti közlekedés}

\section{3. ábra: Mért és számított gyorsítási energia értékek Siemens Taurus mozdony von- tatta szerelvények esetén}

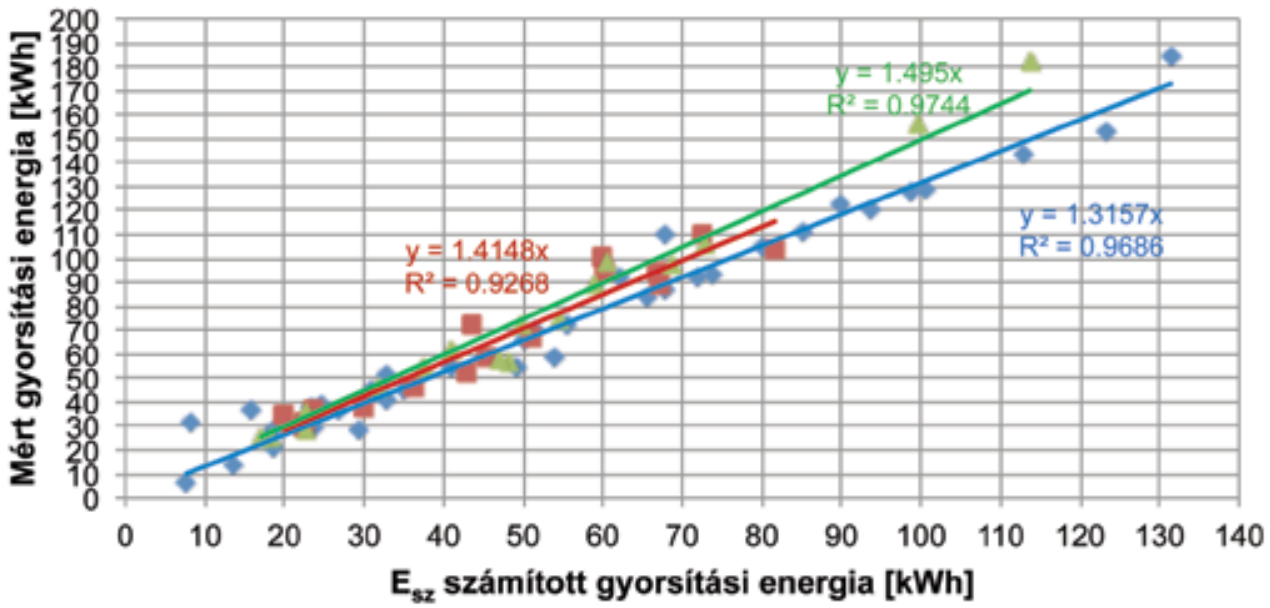
- Railjet
A Taurus_tehervonat
Taurus_személyszállitó vonat
_Linear (Taurus_személyszállitó vonat)
L Linear (Railjet)
- Linear (Taurus_tehervonat)

\begin{tabular}{|c|c|}
\hline Vonatnem & $\begin{array}{c}\text { a tényező } \\
\text { értéke }\end{array}$ \\
\hline Railjet & 1,316 \\
\hline Taurus és személyszállító vonat & 1,415 \\
\hline Taurus és tehervonat & 1,495 \\
\hline V63 és személyszállító vonat & 1,330 \\
\hline V63 és tehervonat & 1,608 \\
\hline V43 és személyszállító vonat & 2,121 \\
\hline V43 és tehervonat & 2,423 \\
\hline Stadler Flirt motorvonat & 1,128 \\
\hline Bombardier Talent motorvonat & 1,095 \\
\hline
\end{tabular}

A 4. ábra bemutatja egy Siemens Taurus mozdony vontatta 500 t tömegü személyszállító gyorsvonat, illetve 2000 t tömegü tehervonat gyorsítási energia értékeit, különböző nagyságú gyorsítási sebességlépcsők függvényében. A számítások bruttó 29,87 Ft/kWh áram egységárat alapul véve készültek.

A 2010. november 1. és 2011. október 31. közötti egy éves időtartamra számítottam ki a Budapest-Kelenföld - Győr vasútvonal mind- két vágányára a lassújelek utáni gyorsítások energiaköltségét. A számításhoz rendelkezésre álltak a napi átgördült elegytonna értékek vágányonkénti, illetve vontatójárművenkénti bontásban (MÁV FVS tablók adatai), valamint a MÁV Zrt. Győri Pft. Főnökség (korábban Pft. Alosztály) statisztikájából a sebességkorlátozások listája havi összesítésben, mindkét vágányra vonatkozóan. A vontatási célú villamos energia árát havi bontásban bocsátotta rendelkezésre a MÁV Zrt. Pályalétesítményi Főosztály. A kalkulációban csak a Siemens Taurus mozdony vontatta Railjet személyszállító gyorsvonatokat, valamint tehervonatokat, illetve a Stadler Flirt és Bombardier Talent motorvonatokat vettük figyelembe. Végeredményként a sebességkorlátozások miatti gyorsítások energiaigénye 32.675 .445 kWh értékre adódott a 2010. november 1. és 2011. október 31. közötti időszakra. Így a kizárólag a sebességkorlátozások miatti lassításokat követő felgyorsítások miatt szükséges többlet költség bruttó 938,3 millió Ft-ra adódott.

A számítások, elemzések alapján a következő fontosabb alapelvek hangsúlyozását tartom 


\section{Vasúti közlekedés}

\section{4. ábra: Egyetlen gyorsítás költsége a sebességlépcső nagyságának függvényében}

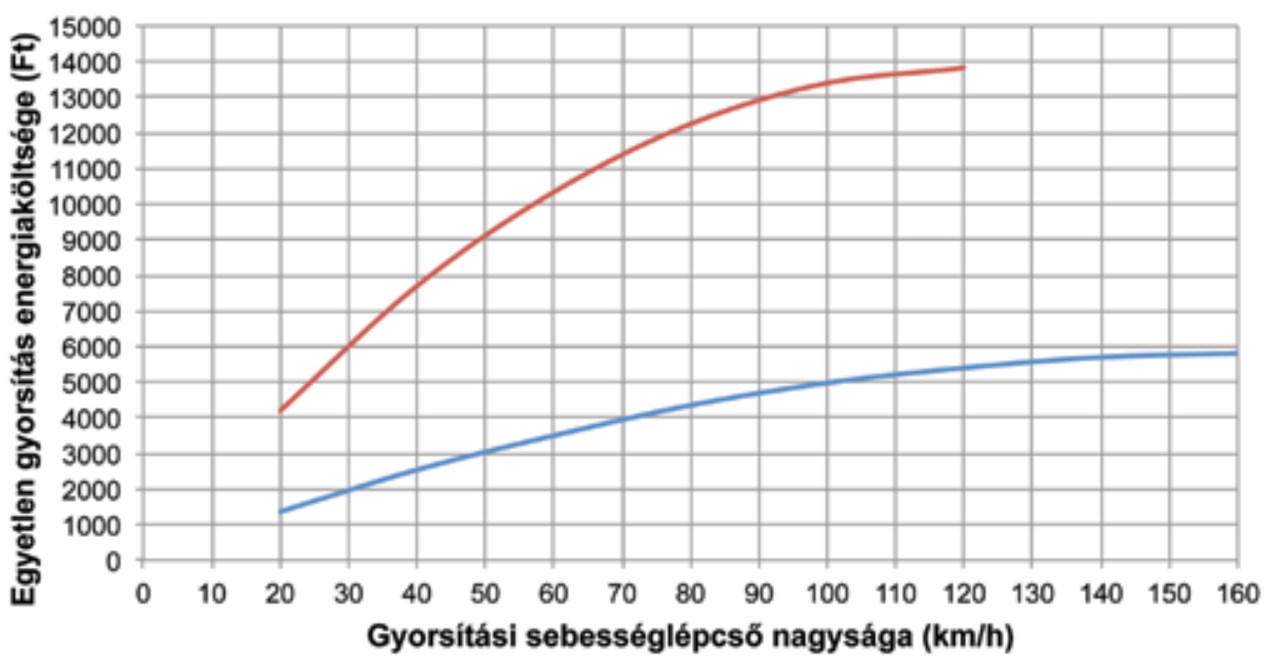

— Személyszállitó vonat (500 tonna)

- Tehervonat (2000 tonna)

szükségesnek egy általános, hálózati mértékű sebességkorlátozásokat megszüntető programmal kapcsolatosan:

- A vasútvonalakat az átgördült elegytonna, a lassújelek utáni gyorsítások energiaigénye és darabszáma szerint rangsorolni kell.

- A sebességkorlátozást okozó, újonnan kialakult pályahibát a lehető leghamarabb ki kell javítani, nem szabad a pályában hosszabb ideig megtürni.

- A pályahibák kijavításának ütemezésekor arra kell törekedni, hogy először nagy számban szüntessük meg azokat a lassújeleket, amelyek felszámolása viszonylag kisebb költséggel megoldható. (A lassújel utáni gyorsítási energiaigény költsége független a lassújelet okozó pályahiba kijavítási költségétől.)

- Gazdaságossági szempontból a munkák időbeli ütemezésénél elöre sorolandó azon sebességkorlátozások megszüntetése, amelyek nagyobb gyorsítási energiaveszteséget okoznak.

- Gyorsvonatok, IC, EC, EN vonatok, Railjetek, valamint tehervonatok szempontjából a menetrend szerinti megállást nem jelentő állomások lassújeleinek felszámolása is lényeges, míg a személyvonatok esetén kizá- rólag a nyíltvonali lassújelek megszüntetése eredményez jelentős csökkentést a gyorsítási energiában.

- A már folyamatban lévő, nagyobb hosszra kiterjedő hibák javításánál el kell kerülni az újabb sebességlépcsők kialakulását. (Ha a hibás szakasz közepét egy helyen javítják, akkor az eredeti egy helyett két sebességlépcsőt hoznak létre.)

\section{A SÍNFEJ-HAJSZÁLREPEDÉS HI- BÁK KIALAKULÂSA ÉS A JELENSÉG KEZELÉSE}

A MÁV egyes vonalain a kétezres évek első évtizedében jelent meg tömegesen egy olyan új típusú, veszélyes hiba, amely a sínfejben a nyomtávsaroknál sürün elhelyezkedő repedések formájában alakul ki (5. ábra). Ez a gördülési érintkezési hibák egyik fajtája: a sínfejhajszálrepedés ún. Head Check (HC) hiba. A jelenség veszélye abban rejlik, hogy a hibafejlődés során a hajszálrepedések behatolnak a sínkeresztmetszetbe. Elöször felületi kitöredezések alakulnak ki, majd a súlyosabb fázisban akár hirtelen fejkitöréshez vagy teljes keresztmetszetü síntörésekhez vezethetnek. 


\section{Vasúti közlekedés}

\section{5. ábra: „S” alakú sínfej-hajszálrepedések}

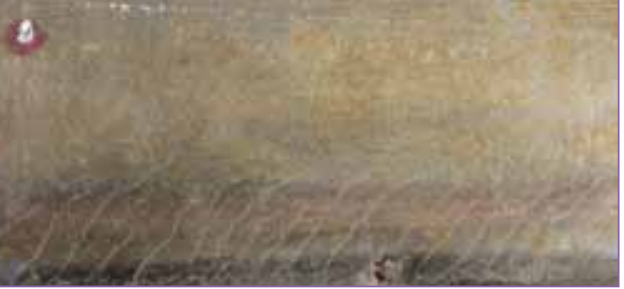

A hibák folyópályában elsősorban $\mathrm{R}=400$ 3000 m sugarú, túlemelt ívek külső sínszálában, míg kitérők esetében főleg az íves csúcssínnél és a keresztezési csúcsbetétnél fordulnak elő. Az ívben haladáskor fellépő centrifugális erő, kitérőkben pedig a síndőlés hiánya is azt okozza, hogy a külső sínszálon a kerék - sín érintkezési felület a nyomtávsarok felé tolódik el. Ezen az érintkező felületen nagyon jelentős nyomó és csúsztató feszültségek lépnek fel, amelyek hatására - a sínacél osztályától függően - egy kb. 0,4 - 1,2 mm vastag, a jármükerekek által hidegen alakított réteg keletkezik, amelyben a keménység nagyon jelentősen, az alapszövetének akár másfélszeresére is megnövekszik. A felkeményedett kéregben bekövetkezik az anyag alakváltozó-képességének kimerülése, amely repedések megjelenéséhez vezet. A felkeményedett kérgen áthatolva a repedés a szemcsék nyúlási irányát követve halad egyre mélyebbre a sínfejbe (6. ábra).

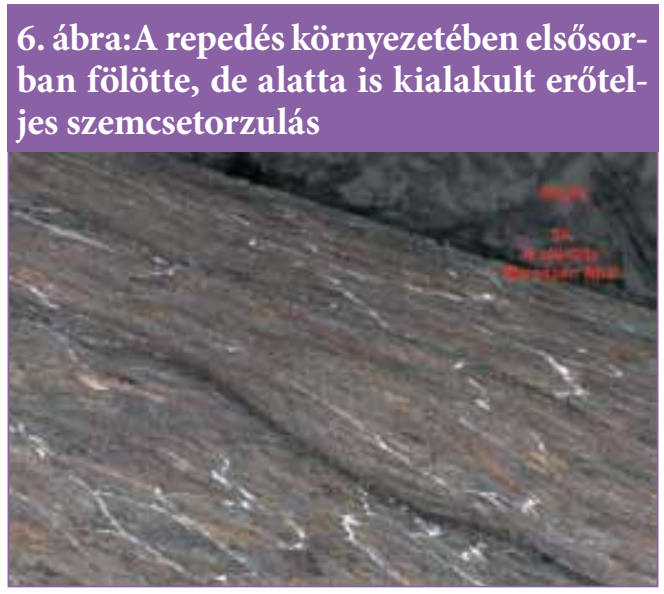

A repedések térben változó mélységü, egymás alá hatoló felületeket alkotnak, ahogyan azt a 7. ábra mutatja, amelyet YXLON Modular típusú ipari CT berendezésünkkel készített felvétel számítógépes feldolgozásával készült. A bal felső ábrarészen a kimunkált mintadarab sínfejben elfoglalt eredeti helyzete látható.

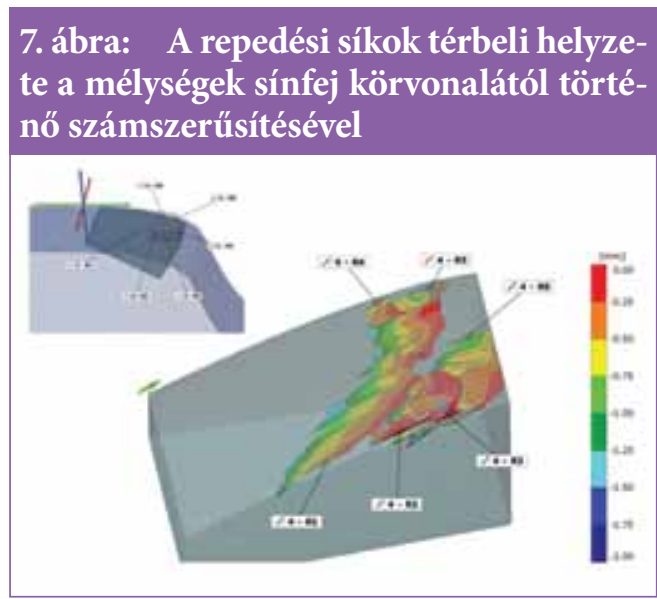

A HC hibák kialakulásának megelőzését, illetve a hiba fejlődésének jelentős mértékű lassítását két mód szolgálja. Az egyik a sínacélosztály megválasztása, azaz nagyobb fejkeménységű sínek beépítése, míg a másik az ún. AntiHeadCheck (AHC) sínprofil alkalmazása.

A műszakilag és pénzügyileg összehangolt gyakorlat alapján a sínkarbantartásnak a károsodások kezelésére három mód létezik:

- megelőző (preventív) síncsiszolás, illetve sínköszörülés, új építések és felújítások esetében,

- ciklikus sínmegmunkálás (általában sínköszörülés) hálózati szemlélettel,

- javító munka többé-kevésbé rövid szakaszokon, szétszórva a hálózaton, a súlyosabb károsodások kezelésére (pl. sínmarás).

A sínfej-hajszálrepedések tekintetében ma a hazai hálózatot meglehetősen nagy anyagi áldozatokkal kezelhető helyzet jellemzi. Az elmúlt évek intenzív munkái jelentősen csökkentették a sínfej-hajszálrepedések miatt bevezetett sebességkorlátozások számát, de még évekig szükség lesz hosszabb távú, átmeneti stratégia alkalmazására, amely 


\section{Vasúti közlekedés}

- a forgalombiztonságot szem elött tartva megszünteti a veszélyes mértékü $\mathrm{HC}$ repedéseket (javító sínköszörülés, illetve síncsere),

- megkezdi egy müszakilag helyes és gazdaságilag kedvező rendszerre az áttérést (pl. azokon a felújított vonalakon, ahol várható a HC hibák megjelenése, elvégzi a megelőző sínköszörülést, s többéves tervezéssel előkészül a ciklikus sínköszörülés bevezetésére),

- majd végül áttér a helyes síngondozási stratégiára hálózati méretben.

A hézagnélküli vágányokban előforduló HC hibák hálózati szintü mérésére a MÁV KFV Kft. üzemeltetésében müködtetett síndiagnosztikai szerelvény (SDS) illetve az új FMK 008 síndiagnosztikai mérőkocsi alkalmas, amelyek az örvényáramos elv alapján észlelik ezeket a hibákat. A vizsgálat során mindkét sínszálon 4-4 db örvényáramos szonda diagnosztizálja a sín futófelületén kialakult hajszálrepedéseket. (Kitérők vizsgálatára a Rohmann $\mathrm{GmbH}$, illetve a Metalelektro saját fejlesztésű kézi készülékei alkalmasak.)

A nagygépes mérőrendszerek egy-egy sínszálra az alábbi eredményeket szolgáltatják:

- számított ún. károsodási mélység értéke méterenként, szondánként, a tartomány: 0,01 $3,00 \mathrm{~mm}$,

- repedés darabszám méterenként, szondánként.
Végül az irodai rendszer készítette jegyzőkönyvben, a vágány szelvényezése függvényében már nem szondánkénti eredmények nyerhetők egy adott méterre vonatkozóan, hanem megadott kiértékelési hosszra (általában $20 \mathrm{~m}$ ) egy, a legkritikusabb mélységü $\mathrm{HC}$ repedésre jellemző adat, mind a károsodási mélység, mind pedig a $\mathrm{HC}$ repedés darabszám tekintetében.

Az Excel táblázatban összesített mérési adatok további feldolgozása során képet kaphatunk a mérés időpontjában jellemző állapotról és több mérés adatainak együttes feldolgozása révén az állapot változásáról. A 8. ábra egy $\mathrm{R}=1000 \mathrm{~m}$ sugarú, $\mathrm{m}=120 \mathrm{~mm}$ túlemelésű balos ív jobb (túlemelt) sínszálában mutatja a károsodási mélységeket a szelvényezés függvényében. 2014. április és 2016. április között erősen romlott az állapot, amit a 2016. év decemberi sínköszörülés nagyon jelentősen javított.

Bár a változások a 8. ábra alapján is érzékelhetők, de sokkal kifejezőbb a 9. ábra, amelyen az öt különböző időpontban mért károsodási mélység értékek eloszlásgörbéi láthatók. A dátum szerint az első négy mérés diagramvonalainak jobbra „vándorlása” mutatja az állapot romlását. A 2015. évi kettő és a 2016. évi áprilisi mérés láttatja, hogyan nőtt meg a $3 \mathrm{~mm}$ vagy annál nagyobb mélységek aránya $6 \%$-ról 11\%-ra, majd 40\%-ra.. (A mérés jellegzetessége, hogy annak során a 3 mm-nél nagyobb értékek is a $3 \mathrm{~mm}$-es kategóriába kerülnek.)

\section{8. ábra: A károsodási mélységek alakulása az idó függvényében}

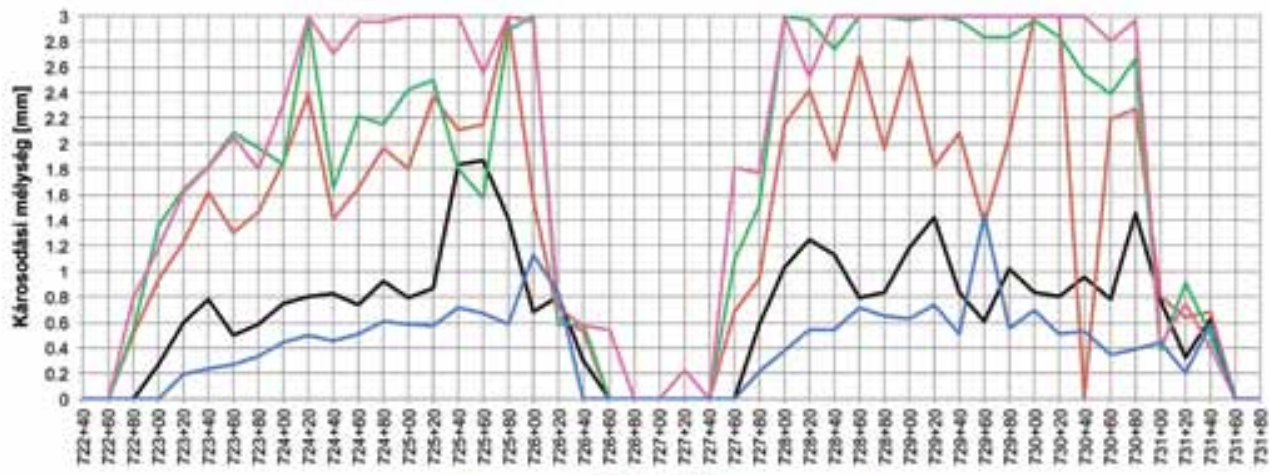




\section{Vasúti közlekedés}

\section{9. ábra: A károsodási mélységek eloszlásgörbéinek változása}

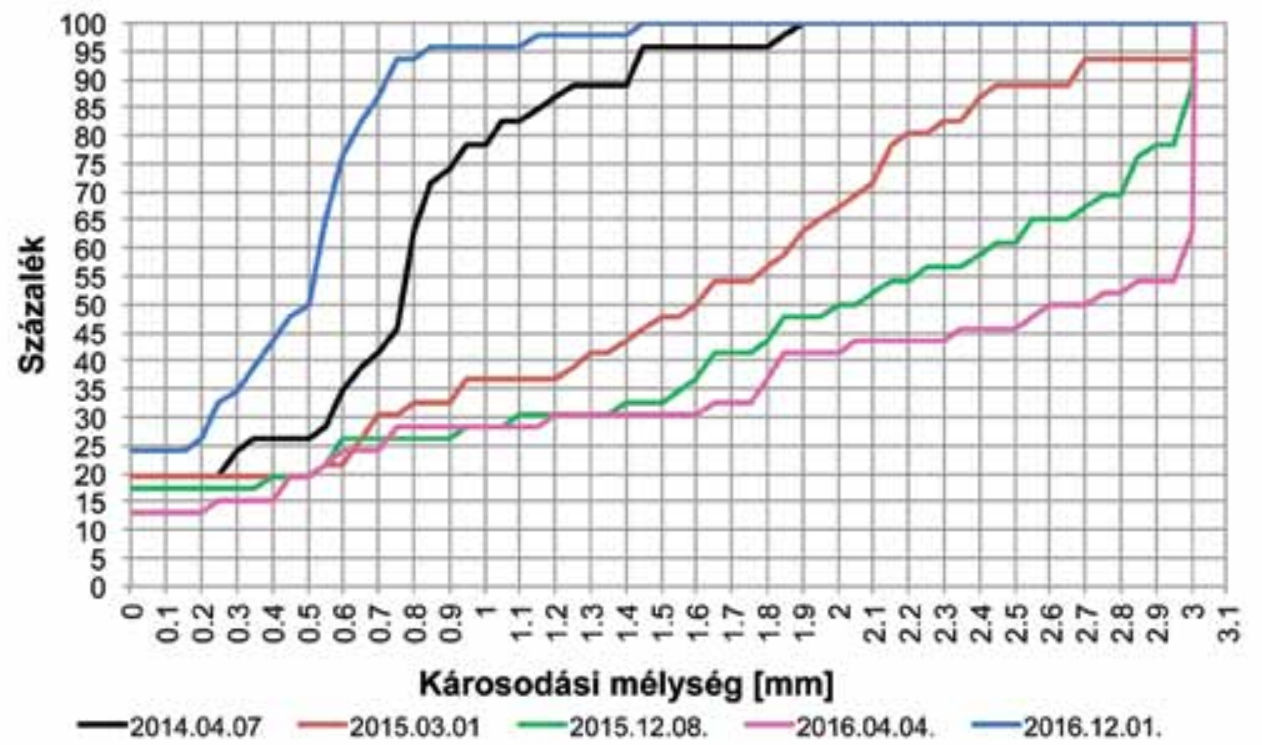

Az eloszlásgörbék helyzetének változását és ezzel a romlási folyamatot az alakszámok segítségével lehet jellemezni. Az alakszám az eloszlásgörbe függőleges tengelyre vett másodrendü nyomatéka. Egy adott eloszlásgörbéhez csak egyetlen alakszám tarto- zik és viszont, így számszaki jellemzésre alkalmas. A 10. ábrán az alakszámok alakulása látható, az első méréstől (2014.04.07.) eltelt idő függvényében. Az első három időközben tapasztalt romlás közel lineárisnak tekinthetö.

\section{0. ábra: Az alakszámok változása az idő függvényében}

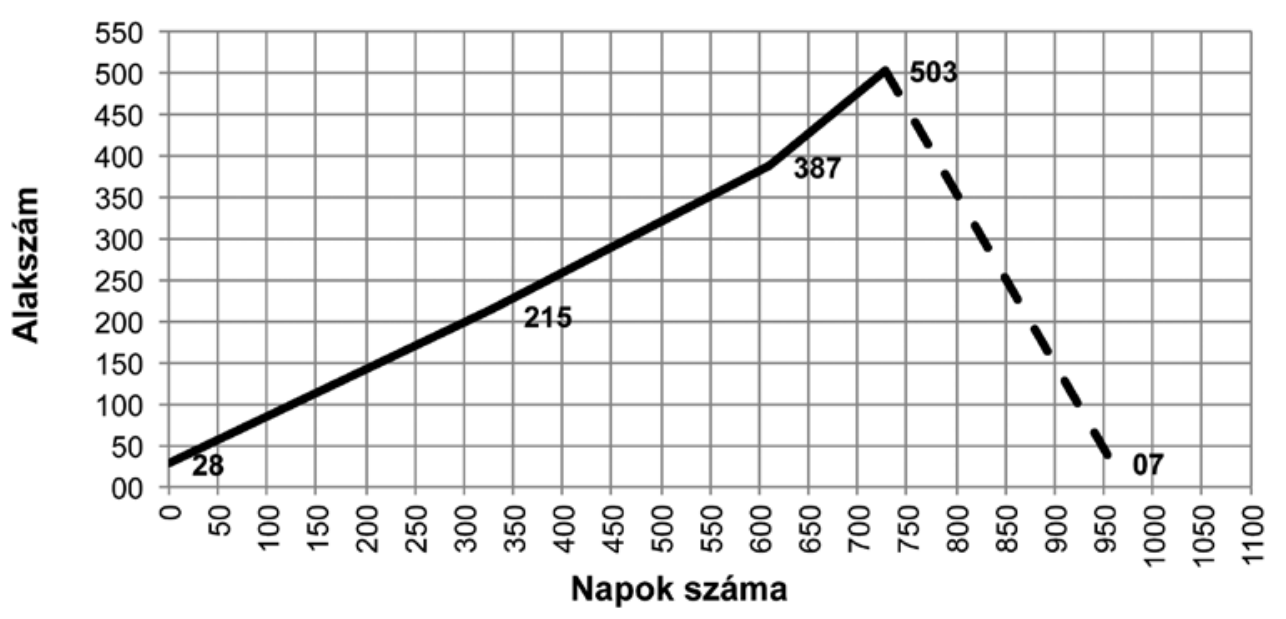




\section{Vasúti közlekedés}

Az alakszámok változását az időszak alatt elviselt bruttó forgalmi terheléssel elosztva olyan mérőszámot kapunk, amely az előidéző ok intenzitását is figyelembe veszi.

$\Delta A=\frac{A_{i}-A_{i-1}}{F}$, ahol

$\Delta \mathrm{A}=$ az alakszám változása az i-1-dik és i-edik időpontban lezajlott két mérés között,

$A_{i}=a z$ alakszám értéke az i-edik mérés során,

$\mathrm{A}_{\mathrm{i}-1}=$ az alakszám az i-1-edik mérés során,

$\mathrm{F}=$ forgalmi terhelés a két mérési időpont (i-1 és i) között.

Az elvégzett munkáltatás hatékonyságát kifejező mérőszám:

$$
H=\frac{A_{e}-A_{u}}{A_{e}} \cdot 100, \text { ahol }
$$

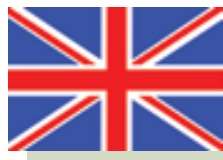

The Results of our Scientific Research and Development Work on the Establishment and Behaviour of the Railway Track

An important criterion for university education is to be as close as possible to the everyday practice of the relevant academic field, as, in addition to solving routine tasks, students need to be prepared for the complex, creative use of knowledge. The tutors should always be up-to-date and follow technical progress, and help in solving the professional problems that require a high level of knowledge and the use of infrastructure offered by the university. The success of a university can be measured, besides the quality of the education it offers, by the results of its research and development that benefit the industry (the customer), but are equally important for the university. Namely, the new knowledge can instantly be incorporated into the education, and it can support the research of new scientific topics. The activity also creates revenue, which is not a negligible aspect as the maintenance and development of the instrument fleet requires significant yearly expenditures. The article briefly describes the features of the research and development work, and presents the results of two previously developed topics.
$\mathrm{A}_{\mathrm{e}}=\mathrm{az}$ alakszám értéke a munkáltatás elött,

$\mathrm{A}_{\mathrm{i}}=\mathrm{az}$ alakszám értéke a munkáltatás után.

\section{FELHASZNÁLT IRODALOM}

[1] Villamos vontatással üzemeltetett vasúti pályákon a sebességkorlátozások okozta többletköltségek csökkentési lehetőségeinek komplex vizsgálata. 95-3106-25 számú K+F munka zárójelentése. Készítette: Széchenyi István Egyetem Közlekedésépítési és Településmérnöki Tanszék, Győr, 2012.10.31.

[2] Sínfej károsodási hibák kezelése, karbantartási technológiájuk kidolgozása. Müszaki követelmények meghatározása a gazdaságossági szempontok figyelembevételével. 311-291 számú $\mathrm{K}+\mathrm{F}$ munka zárójelentése. Készítette: UniversitasGyőr Nonprofit Kft., Győr, 2014.11.30

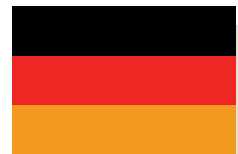

\section{Die Ergebnisse unserer wissenschaftlichen \\ Forschungs- und} Entwicklungsarbeiten im Bezug zum Ausbau und Verhalten der Eisenbahnstrecke

Ein wichtiges Kriterium für die Universitätsausbildung ist es, der Alltagspraxis des jeweiligen akademischen Feldes so nahe wie möglich $\mathrm{zu}$ kommen, denn neben der Lösung von Routineaufgaben müssen die Studierenden auf die komplexe, kreative Benutzung ihres Wissens vorbereitet sein. Die Tutoren sollen dem technischen Fortschritt folgen und zur Lösung der beruflichen Probleme beitragen, die ein hohes Maß an Wissen und die Nutzung der von der Universität angebotenen Infrastruktur erfordern. Der Erfolg einer Universität lässt sich neben der Qualität der angebotenen Ausbildung an den Ergebnissen ihrer Forschung und Entwicklung messen, die der Industrie (dem Auftraggeber) zu Gute kommen, aber auch für die Universität von Bedeutung sind. Denn das neu erschaffene Wissen kann sofort in die Ausbildung einfließen und die Erforschung neuer wissenschaftlicher Themen unterstützen. Die Aktivität schafft auch Einnahmen, was kein vernachlässigbarer Aspekt ist, da die Wartung und Entwicklung des Instrumentenbestands beträchtliche jährliche Ausgaben erfordert. Der Artikel beschreibt kurz die Merkmale der Forschungs- und Entwicklungsarbeit und stellt die Ergebnisse von zwei zuvor erarbeiteten Themen vor. 